\title{
Tensile strength of 3D textiles reinforced cementitious composites plates
}

\author{
Ikbal Gorgis ${ }^{1}$, Waleed Abbas ${ }^{1}$, and Nadia Moneen ${ }^{2, *}$ \\ ${ }^{1}$ Building and Construction Engineering Department, University of Technology, Baghdad, Iraq \\ ${ }^{2}$ Al- Najaf Technical Institute, Najaf, Iraq
}

\begin{abstract}
Tensile plate specimens with dimension of $450 \times 100 \times 40 \mathrm{~mm}$ were cast with $3 \mathrm{D}$ glass fabric having three different thicknesses 6,10 and $15 \mathrm{~mm}$ to measure their tensile strength. Plates with one and two layers of chicken wires, as well as micro steel fiber of $0.75 \%$ volume fraction were tested under tensile for comparison with references plates. Cement mortar with $61.2 \mathrm{MPa}$ cube compressive strength at 28 days was designed for casing the plates. The results indicated that after cracking of the mortar the textile reinforcement adds a strain hardening trajectory, that cause failure to occurs at slightly higher load and a higher strain. The improvement in tensile strength at 28 days ranged between 5 to $30 \%$, and for 90 days between 5 to $60 \%$ for the three types of fibres used. Based on the results a significant increase was indicated with micro steel fiber.
\end{abstract}

\section{Introduction}

The mechanical possibilities and advantages of Textile Reinforced Mortar have been proven, both as strengthening material and as precast material (in this field this composite is also called Textile Reinforced Concrete TRC) [1\&2]. As Textile Reinforced Mortar (TRM) usually bears tensile loads, it is very relevant to investigate the behaviour of this material under pure tensile loads.

The tensile strength can be determined approximately by direct tensile specimens. Usually tensile strength of normal brittle concrete is less imperative, but not in the case of steel fibre reinforced concrete, since steel fibres influence the ductility [3]. Tensile testing is performed to understand the material behaviour of fibre reinforce cementations composites in tension and to determine the values necessary for analysis and design of structural elements. To provide accurate material characteristics for design, the geometric relationships between the microstructure and the stresses in the test specimens as well as the boundary conditions must correlate to those in the product to be designed [4]. The load bearing behaviour of textiles as reinforcement can be seen similar to steel reinforced concrete (SRC) since the reinforcement is aligned in the direction of the tensile strength. The main difference in the load bearing behaviour between textile reinforced concrete (TRC) and steel reinforced concrete (SRC) is the bonding between the reinforcement and the concrete matrix. The reinforcement bars in steel reinforced concrete (SRC) are profiled to transfer forces between the reinforcement and concrete. In (TRC) the reinforcement yarns of the textile work on adhesion and friction. When a yarn in the textile structure consist of multiple non-twisted filaments the full tensile strength cannot be utilized, since only a part of the yarns has direct bonding with the concrete matrix (because a part of the yarn gets impregnated with concrete). Tensile test on textile reinforced concrete (TRC) specimen was done. It was found that the behaviour was the same as steel reinforce concrete (SRC)[5]. This behaviour can be described in three stages.

From previous experiments, it was observed that the (TRC) specimen has lower (10 to $30 \%$ ) stiffness than the textile itself. This has been explained by the failure of a small part of the filaments during the cracking stage. Unlike steel reinforcement, textile reinforcement does not show plastic behaviour. Although the reinforcement does not deform in a plastic way, (TRC) does not fail in a brittle way due to pull-out of the fibres. Figure (1b) shows the stress-strain diagram for multiple types of TRC specimens loaded with a centric tensile force [6].

The influences of geometric patterns of 3D spacer fabric on the tensile behaviour of concrete canvas were investigated [7]. Tensile stress-strain curves and crack propagating patterns of concrete canvas were obtained in warp and weft directions through experiments. The average values of three parallel samples were acquired for different concrete canvas in warp and weft direction, respectively. Experimental results revealed that the concrete canvas samples reinforced by the $3 \mathrm{D}$ spacer fabrics exhibited improved tensile behaviours in terms of tensile strength, reinforcing efficiency factor and crack pattern. Moreover, for concrete canvas, 3D spacer fabric reinforcement was a better option than spacer yarns alone.

\footnotetext{
* Corresponding author: nadia.material $@$ gmail.com
} 
Experimental program to evaluate the mechanical properties of cement-based composites were carried out [8]. The variables were water to cement $(\mathrm{w} / \mathrm{cm})$ ratios, silica fume (SF) percent and volume fraction of steel fibre. Compressive strength, direct tensile strength, and drop weight tests were performed. It was found that cement-based composites containing $10 \% \quad \mathrm{SF}$ demonstrates better compressive strength, direct tensile strength and abrasion resistance, and worse impact resistance than composites containing 5\% SF. The 10\% SF specimens with $\mathrm{w} / \mathrm{cm}$ of 0.35 and 0.65 have $18 \%$ and $15 \%$ higher compressive strength, $3 \%$ and $8 \%$ higher direct tensile strength, $83 \%$ and $62 \%$ lower impact toughness than the control specimen. The addition of steel fibre to SF composites achieve $10 \%$ and $9 \%$ increase in compressive strength, $31 \%$ and $15 \%$ increase in direct tensile strength, and $418 \%$ and $296 \%$ increase in impact toughness. Lightweight concrete with ferrocement subjected to axial tension was studied [9], in which blast furnace slag with sand was used. Steel galvanized woven square mesh of $4 \times 20$ gauge with $6.35 \mathrm{~mm}$ diameter of wire is used. Sand was replaced by blast furnace slag in the range of $0 \%, 20 \%, 35 \%$, and $70 \%$. Five volume fractions had been used for total 6 layers of mix proportion of in ratio 1: 2 with w/c of 0.5 . The result showed that the replacement of blast furnace till $20 \%$ cause maximum increase in axial tension strength while any increase in blast furnace slag to $35 \%$ and $70 \%$ shows decrease in strength. Tensile strength of specimen was found to be directly proportional to the number of mesh layers.

Enhancement of the load carrying capacity of mortar of cement sand ratio $1: 2$ with w/c of 0.45 was investigated [10]. Using wire mesh with diameter of 0.94 $\mathrm{mm}$ and grid size of $(12 \times 12 \mathrm{~mm})$ welded. Plain concrete with ferrocement jacket provides remarkable lateral confinement pressure which increases axial load carrying capacity.

An experimental study [11] on the direct tensile strength of plates by using different numbers of wire mesh and inducing steel fibres with, keeping constant thickness of plates. Wire mesh layers ranged from (1-6) layers, test specimens used were $300 * 50 \mathrm{~mm}$ with a uniform thickness. Steel fibres with volume fraction of $0.5 \%$ of total volume of composite were added. Test result indicates that; direct tensile strength is directly proportional to the number of mesh layers used. Steel fibres usage increases tensile strength by about (10 to 17 ) $\%$ as compared with specimens without steel fibres.

In this work more than 60 plate specimens were cast with 3D glass fabric having three different thicknesses 6 , 10 and $15 \mathrm{~mm}$ and different number of layers to measure their tensile strength. Plates with one and two layers of chicken wires, as well as to plates with micro steel fibre of $0.75 \%$ volume fraction were tested under tensile for comparison with references plates. Cement mortar with 61.2MPa cube compressive strength at 28 days was designed for casing the plates.

\section{Experimental work}

An experimental program was devoted in this work to investigate the structural behaviour of self-compact reinforced concrete plates subjected to tensile load. Test Specimens with dimension $(450 \times 100 \times 40) \mathrm{mm}$ were divided into six croups according to the fibre reinforcement thickness, layers, direction of reinforcement, and type of reinforcement. First group consisted of plates cast with self-compact mortar (SCM) without any reinforcement; the second group was reinforced with $6 \mathrm{~mm} 3 \mathrm{D}$ glass textile fibre, reinforced with one layer, two layers. Third group cast with $10 \mathrm{~mm}$ 3D glass textile fibre with one and two layers, while the fourth group contains $15 \mathrm{~mm}$ 3D glass textile fibre casted with one layer only. The fifth plate group consisted of self-compact mortar reinforced with chicken wire casted with one and two layers, the sixth group reinforced with micro steel fibre of $0.75 \%$ volume fraction, three specimens were casted for each test age (28 and 90) days. All details of the specimens are shown in Table (1).

Table 1. Details of test specimens.

\begin{tabular}{|c|c|c|c|c|}
\hline \multirow{2}{*}{$\begin{array}{l}\dot{z} \\
\vdots \\
\ddot{z} \\
\dot{0}\end{array}$} & & \multirow[t]{2}{*}{ Mix Symbol } & \multicolumn{2}{|c|}{$\begin{array}{c}\text { Direct Tensile Test } \\
450 \times 100 \times 40 \\
\mathrm{~mm}\end{array}$} \\
\hline & & & 28 days & 90 days \\
\hline 1 & Ref. & Without any fiber & 3 & 3 \\
\hline \multirow[b]{2}{*}{2} & F6-1 & $\begin{array}{l}\text { Glass fiber } 6 \mathrm{~mm} \\
\text { thickness (one layer). }\end{array}$ & 3 & 3 \\
\hline & F6-2 & $\begin{array}{l}\text { Glass fiber } 6 \mathrm{~mm} \\
\text { thickness (two layers). }\end{array}$ & 3 & 3 \\
\hline \multirow[t]{2}{*}{3} & F10-1 & $\begin{array}{l}\text { Glass fiber } 10 \mathrm{~mm} \\
\text { thickness (one layer). }\end{array}$ & 3 & 3 \\
\hline & F10-2 & $\begin{array}{l}\text { Glass fiber } 10 \mathrm{~mm} \\
\text { thickness (two layers). }\end{array}$ & 3 & 3 \\
\hline 4 & F15 & $\begin{array}{l}\text { Glass fiber } 15 \mathrm{~mm} \\
\text { thickness (one layer). }\end{array}$ & 3 & 3 \\
\hline \multirow{2}{*}{5} & FS-1 & $\begin{array}{l}\text { Mesh chicken wire (one } \\
\text { layer). }\end{array}$ & 3 & 3 \\
\hline & FS-2 & $\begin{array}{l}\text { Mesh chicken wire (two } \\
\text { layers). }\end{array}$ & 3 & 3 \\
\hline 6 & M S F & $\begin{array}{l}\text { With } V_{f}=0.75 \text { micro } \\
\text { steel fiber }\end{array}$ & 3 & 3 \\
\hline
\end{tabular}

\subsection{Materials properties}

The properties of materials used in the preparation of the tested reinforced and unreinforced self-compact mortar are described below:

1- Cement: Ordinary Portland cement (type I) from Krasta Factory was used to cast all the specimens, the chemical composition and physical properties are listed in Table (2). It conforms to the requirements of the Iraqi Standard Specification IQS. No. 5 /1984 [12].

2- Fine aggregate: Natural sand from Najaf sea region was used with $0.6 \mathrm{~mm}$ maximum size. The results of physical and chemical properties of the sand are listed in Table (3). Test results comply with the requirements of the Iraqi Standard Specification IQS. No.45-1984 [13]. 
3- Water: Ordinary water tape was used for both casting and curing all specimens.

4- High Range Water Reducing Admixture (HRWRA): A high performance concrete superplasticizer (also named High Range Water Reduction Agent HRWRA) based on polycarboxylic technology, known commercially as Glenium 54 was used. It is produced by BASF Company and conforms to ASTM C 494 Type F [14]. Table (4) shows its properties.

Table 2. Chemical and physical properties of the cement

\begin{tabular}{|c|c|c|}
\hline Oxide & $\%$ & $\begin{array}{l}\text { I.O.S. 5: } 1984 \\
\text { Limits }\end{array}$ \\
\hline $\mathrm{CaO}$ & 66.11 & 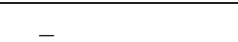 \\
\hline $\mathrm{SiO}_{2}$ & 21.93 & - \\
\hline $\mathrm{Al}_{2} \mathrm{O}_{3}$ & 4.98 & - \\
\hline $\mathrm{Fe}_{2} \mathrm{O}_{3}$ & 3.10 & - \\
\hline $\mathrm{MgO}$ & 2.0 & $<5.0$ \\
\hline $\mathrm{K}_{2} \mathrm{O}$ & 0.75 & \\
\hline $\mathrm{Na}_{2} \mathrm{O}$ & 0.35 & \\
\hline $\mathrm{SO}_{3}$ & 2.25 & $<2.8$ \\
\hline Loss on Ignition (L.O.I) & 2.39 & $<4.0$ \\
\hline Lime Saturation Factor & 0.93 & $0.66-1.02$ \\
\hline (L.S.F) Insoluble residu & 1.29 & $<1.5 \%$ \\
\hline Free lime (F.L) & 0.67 & - \\
\hline Compound Composition & $\%$ & $\begin{array}{l}\text { I.O.S. 5: } 1984 \\
\text { Limits }\end{array}$ \\
\hline $\mathrm{C}_{3} \mathrm{~S}$ & 58.16 & \\
\hline $\mathrm{C}_{2} \mathrm{~S}$ & 19 & - \\
\hline $\mathrm{C}_{3} \mathrm{~A}$ & 7.95 & - \\
\hline $\mathrm{C}_{4} \mathrm{AF}$ & 9.43 & \\
\hline Physical Properties & Test Result & $\begin{array}{l}\text { I.Q.S.5:1984 } \\
\text { Limits }\end{array}$ \\
\hline $\begin{array}{l}\text { Fineness, Blaine, } \\
\mathrm{cm}^{2} / \mathrm{gm}\end{array}$ & 3300 & $>2300$ \\
\hline $\begin{array}{l}\text { Setting Time: } \\
\text { Initial hrs.; min } \\
\text { Final hrs.; min }\end{array}$ & $\begin{array}{c}1 ; 08 \\
4 ; 00\end{array}$ & $\begin{array}{l}\geq 45 \mathrm{~min} \\
\leq 10 \mathrm{hrs}\end{array}$ \\
\hline \multicolumn{3}{|l|}{$\begin{array}{l}\text { Compressive Strength } \\
(\mathrm{MPa})\end{array}$} \\
\hline 3-days & 20,0 & $\geq 15$ \\
\hline 7-days & 25,0 & $\geq 23$ \\
\hline
\end{tabular}

Table 3. Properties of fine aggregate.

\begin{tabular}{|l|c|c|}
\hline $\begin{array}{l}\text { Physical } \\
\text { properties* }\end{array}$ & Test results & $\begin{array}{c}\text { Iraqi specification. } \\
\mathbf{4 5} / \mathbf{1 9 8 4}^{[\mathbf{1 3}]}\end{array}$ \\
\hline Specific gravity & 2.65 & - \\
\hline Sulfate content & $0.3 \%$ & $\begin{array}{c}\text { Not more than } \\
0.5 \%\end{array}$ \\
\hline Absorption & $1 \%$ & - \\
\hline Bulk density $\left(\mathrm{kg} / \mathrm{m}^{3}\right)$ & 1560 & - \\
\hline
\end{tabular}

Table 4. Typical properties of sp (glenium54)*

\begin{tabular}{|c|c|}
\hline Form & Viscous Liquid \\
\hline Commercial name & Glenium 54 \\
\hline $\begin{array}{l}\text { Chemical } \\
\text { composition }\end{array}$ & $\begin{array}{c}\text { Sulphonated melamine and } \\
\text { naphthaline formaldehyde } \\
\text { condensates }\end{array}$ \\
\hline Appearance & Whitish to straw colored liquid \\
\hline Relative density & $1.07 \mathrm{gm} / \mathrm{cm}^{3}$ at $20^{\circ} \mathrm{C}$ \\
\hline Chloride content & Nil. \\
\hline $\mathrm{pH}$ & $5-8$ \\
\hline Storage & $\begin{array}{l}\text { Should be stored in original } \\
\text { containers and at above } 5^{\circ} \mathrm{C}\end{array}$ \\
\hline Transport & Not classified as dangerous \\
\hline Labeling & Not hazard label required \\
\hline $\begin{array}{l}\text { Alkali content (as } \\
\mathrm{NaO}_{2} \text { ) equivalent) }\end{array}$ & $0.26 \%$ \\
\hline
\end{tabular}

*According to manufacturer

\subsection{Additive or mineral admixture}

1- Fly Ash: Class F Fly Ash (FA) produced from Thermal Power plant in Turkey was used as an additive according to ASTM C618 [15], fly ash was used as $20 \%$ by weight replacement of cementitious material. The physical and chemical properties are presented in Table (5).

2- $\quad$ Silica Fume: Silica Fume (SF) produced by BASF Company was used as pozzolanic admixture. Cement was replaced by $5 \%$ of silica fume by weight of cementitious material. The silica fume used in this work conforms to the requirements of ASTM C-1240-05 [16], ASTM C-311-05[17]. The technical specifications of silica fume are presented in Table (6).

3- 3D textile glass fibre: 3D textile glass fibre woven fabric consists of two bidirectional woven fabric surfaces mechanically connected with vertical woven piles. Two S-shaped piles combine to form pillar, 8shaped in the warp direction and I- shaped in the weft direction. For the use of a textile as reinforcement in concrete, textile should have an open mesh allowing the mortar or concrete to penetrate the textile for good bond between the materials, for this reason, $19 \mathrm{~mm}$ holes at distance $50 \mathrm{~mm}$ center to center - for both direction were drilled (by tool cutters) for the 3D textile glass fibre glass woven; this process must ensure good penetration of the cement matrix Plats (1) shows the surface, thickness and fibres holes). 3D glass fibre textile woven was export from china. Tables (7) and (8) show typical properties, of different-Fabric Specifications.

4- Mesh chicken wire: The Rhombic shape meshes of reinforcement, fabricated from $0.54 \mathrm{~mm}$ - nominal diameter steel bars, the opening in the long and short direction $(10.6,7.92 \mathrm{~mm})$ respectively.

5- Micro steel fibre: Steel fibres are used in selfcompact mortars (SCMs) to enhance some properties and improve the ductility; it was manufactured by Ganzhou Daye Metallic Fibre Co., Ltd, China. (http// www.gzdymf.com), it is subjected to (ISO $9001 / 2008$ ), the properties are summarized in Table (9). After pouring the first layer of self-compact mortars; micro steel fibre $(0.75 \%)$ volume fraction was randomly distributed by hand. See Plate (2) micro steer fibre casted. 
Table 5. Properties of class (f) fly ash*

\begin{tabular}{|c|c|c|}
\hline Particular & $\begin{array}{l}\text { Fly ash (Class } \\
\text { F) }\end{array}$ & $\begin{array}{l}\text { ASTM C } 618 \\
\text { Class F fly ash } \\
{[14]}\end{array}$ \\
\hline \multicolumn{3}{|l|}{$\begin{array}{l}\text { Chemical } \\
\text { composition }\end{array}$} \\
\hline Silica $\left(\mathrm{SiO}_{2} \%\right)$ & 65.65 & \multirow{3}{*}{$\begin{array}{c}\left(\mathrm{SiO}_{2}+\mathrm{Al}_{2} \mathrm{O}_{3+}\right. \\
\left.\mathrm{Fe}_{2} \mathrm{O}_{3}\right) \geq 70\end{array}$} \\
\hline$\%$ Alumina $\left(\mathrm{Al}_{2} \mathrm{O}_{3}\right)$ & 17.69 & \\
\hline $\begin{array}{l}\text { Iron Oxide }\left(\mathrm{Fe}_{2} \mathrm{O}_{3}\right) \\
\%\end{array}$ & 5.98 & \\
\hline Lime $(\mathrm{CaO}) \%$ & 0.98 & \\
\hline Magnesia $(\mathrm{MgO}) \%$ & 0.72 & \\
\hline $\begin{array}{l}\text { \% Sulphur Trioxide } \\
\left(\mathrm{SO}_{3}\right)\end{array}$ & 0.19 & Max. 5.0 \\
\hline Loss on Ignition & 3.1 & Max. 6.0 \\
\hline $\mathrm{Na}_{2} \mathrm{O}$ & 1.35 & \\
\hline $\mathrm{K}_{2} \mathrm{O}$ & 2.98 & \\
\hline \multicolumn{3}{|l|}{ Physical properties } \\
\hline Specific gravity & 2.12 & \\
\hline Fineness $\left(\mathrm{cm}^{2} / \mathrm{gm}\right)$ & 3600 & Min. $2250 \mathrm{~cm}^{2} / \mathrm{gm}$ \\
\hline
\end{tabular}

Table 6. The technical specifications of silica fume

\begin{tabular}{|l|c|c|}
\hline \multicolumn{1}{|c|}{$\begin{array}{c}\text { Structure of } \\
\text { material }\end{array}$} & Silica fume & $\begin{array}{c}\text { Limits of ASTM } \\
\text { C 1240-05 [15] }\end{array}$ \\
\hline Color & Dark gray & \\
\hline Density & $\begin{array}{c}0.55-0.7 \\
\mathrm{~kg} / \mathrm{m}^{3}\end{array}$ & \\
\hline Chlorine amount & $<0.1 \%$ & \\
\hline $\begin{array}{l}\text { Specific surface area } \\
\left(\mathrm{cm}^{2} / \mathrm{gm}\right)\end{array}$ & $\begin{array}{c}>150000 \\
\mathrm{~cm}^{2} / \mathrm{g}\end{array}$ & $\geq 150000 \mathrm{~cm}^{2} / \mathrm{g}$ \\
\hline $\mathrm{SiO}_{2}$ & $>85 \%$ & $\geq 85 \%$ \\
\hline $\mathrm{CaO}$ & $<1 \%$ & \\
\hline $\mathrm{Activity} \mathrm{index*}$ & $156 \%$ & $\geq 105 \%$ \\
\hline Specific gravity & 2.2 & \\
\hline
\end{tabular}

Table 7. Glass fiber woven fabrics specifications*.

\begin{tabular}{|c|c|c|c|c|c|}
\hline $\begin{array}{c}\text { Area } \\
\text { Weight } \\
\mathbf{g} / \mathbf{m}^{2}\end{array}$ & $\begin{array}{c}\text { Core } \\
(\mathbf{m m})\end{array}$ & $\begin{array}{l}\text { Density } \\
\text { of Warp } \\
\text { (ends } \\
\text { /cm) }\end{array}$ & $\begin{array}{c}\text { Density } \\
\text { of Weft } \\
\text { (ends } \\
\text { /cm) }\end{array}$ & $\begin{array}{c}\text { Tensile } \\
\text { Strength } \\
\text { (MPa) } \\
\text { (Warp) }\end{array}$ & $\begin{array}{c}\text { Tensile } \\
\text { Strength } \\
\text { (MPa) } \\
\text { (Weft) }\end{array}$ \\
\hline 900 & 6 & 15 & 10 & 5500 & 9400 \\
\hline 1480 & 10 & 15 & 8 & 6800 & 12000 \\
\hline 1650 & 15 & 12 & 6 & 7200 & 13000 \\
\hline
\end{tabular}

*According to manufacturer.

Table 8. Properties of 3D textile glass fibre woven fabrics specifications.

\begin{tabular}{|l|c|}
\hline \multicolumn{1}{|c|}{ Weight/ area } & From 820 to 2580g/m $\mathbf{m}^{\mathbf{2}}$ \\
\hline Surface Treatment & Silicon Coated \\
\hline Width & $1.3 \mathrm{~m}$ or Made to order \\
\hline Weave Type & Plain Woven \\
\hline Yarn Type & E-Glass \\
\hline Alkali Content & Alkali Free \\
\hline Standing Temperature & $260^{\circ} \mathrm{C}$ \\
\hline Color & White \\
\hline Specific stiffness & Extremely High \\
\hline Woven & parabeam \\
\hline Acoustic insulation & Excellent \\
\hline Wave transmittable & Well \\
\hline Construction & Two layers and one hollow \\
& spacer \\
\hline
\end{tabular}

Table 9. Specification of micro steel fiber*

\begin{tabular}{|l|c|}
\hline \multicolumn{1}{|c|}{ Property } & Specification \\
\hline Type & WSF 0213 \\
\hline Surface & Brass coated \\
\hline Tensile Strength & $2850 \mathrm{MPa}$ \\
\hline Length & $15 \mathrm{~mm}$ \\
\hline Diameter & $0.2 \mathrm{~mm}$ \\
\hline Aspect ratio & 65 \\
\hline
\end{tabular}

* Adopted by manufacturer

\section{Mixing of self-compacting mortar (SCM)}

The proportion of the constituents for the prepared mortar mix is $1: 1$ (cement sand) by weight of ordinary Portland cement and cementitious materials: fine aggregate with $0.6 \mathrm{~mm}$ maximum size. The superplasticizer (SP) had a dosage of 1 liters per $100 \mathrm{~kg}$ of material (cement and binder), w/b of 0.36 was selected for this investigation. The mortar was prepared using a small mechanical mixer conforming to ASTM C305-04 [18]. The mixing procedure is descried below:

First, add cement, fly ash and silica fume in the mixer, operating at low speed for $30 \mathrm{sec}$. until a uniform distribution is reached,

Second, add sand and mix for $1 \mathrm{~min}$. at medium speed, Third, add the first part (2/3) of water and mix thoroughly for $30 \mathrm{sec}$. at low speed, stop $2 \mathrm{~min}$ to clean blades, now, add SP and remaining water and mix for 2 min. at normal velocity, Stop the mixer and wait for 1 min., and then finalize the process by mixing at normal velocity for $3 \mathrm{~min}$.

Finally, do the discharge.

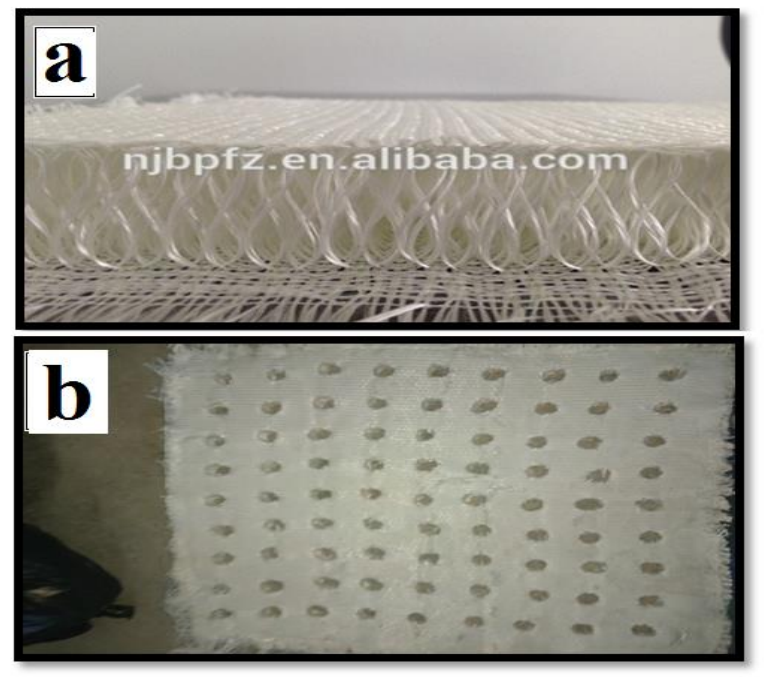

Plates 1. 3D textile glass fiber made in china; a) Zoom view. b) Holes made in 3D glass fiber. 


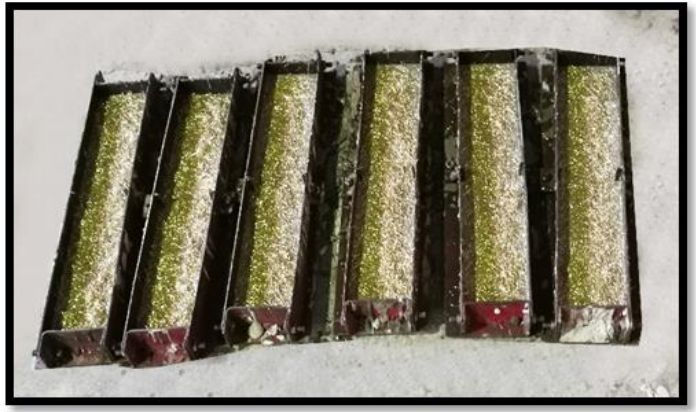

Plate 2. Specimen casted molds for tensile test.

\section{Fresh Mortar properties}

\subsection{Determination of slump-flow}

The test apparatus for measuring the flow and viscosity of mortar comprises a mini slump cone with a graduated glass plate. Slump cone has $70 \mathrm{~mm}$ and $100 \mathrm{~mm}$ top and bottom diameters respectively with height of $(59 \mathrm{~mm})$. The subsequent diameter of the mortar is measured in two perpendicular directions and the average of the diameters is reported. In this test, the truncated cone mold is placed exactly on the $(100 \mathrm{~mm})$ diameter graduated circle marked on the glass plate, filled with mortar and lifted upwards. Fresh properties of mortars were evaluated by the mean value of two perpendicular flow diameters in the spread test. Mortars were prepared manually in a container to observe its behaviour. The procedure for test was followed as described in [19] see Plate 3.

\subsection{Determination of Flow Time}

Flow time was determined in the v-funnel test; the dimension of $v$ - funnel is show in Fig. 1.

\section{Mechanical properties of hardened self- compact mortar}

\subsection{Compressive strength}

This test was done on cubes according to the Standard Specification I.Q.S. No.5/1984[15]. A3000kN capacity testing machine was used for compressive test. The average compressive strength of three cubes $(77 \times 77 \times 77 \mathrm{~mm})$ was recorded for each testing age $(7,28$, 90 days).

\subsection{Flexural strength}

The flexural strength testing is carried out on prisms with $(40 \times 40 \times 160 \mathrm{~mm})$ self-compact mortar prism. The prism is then loaded at its center point until failure. Using three mortar prisms for each age $(28,90)$ days and the average of three results is adopted. A $20 \mathrm{kN}$ capacity Beijing United testing machine was used for this test. The flexural strength is calculated, as follows: -

$$
\mathrm{Fr}=2 \mathrm{PL} /\left(3 \mathrm{bd} \mathrm{d}^{2}\right)
$$

where: fr is the flexural strength [which is measured in (MPa), $\mathrm{P}$ is the maximum load, measured in $(\mathrm{N}), \mathrm{L}$ is the clear span length, measured in $(\mathrm{mm}), \mathrm{b}$ is the width of specimen, measured in $(\mathrm{mm})$, Finally, $d$ is the average depth of specimen, measured in (mm). The mortar prisms were prepared according to ASTM C 348-04[20]. Plate (4) shows the flexural test.

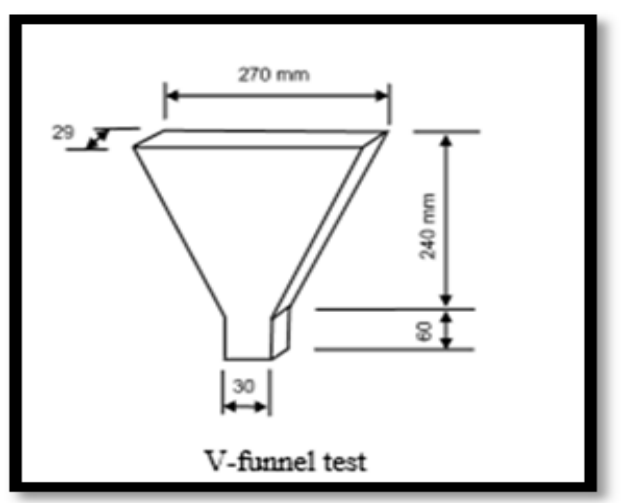

Fig. 1. V-funnel apparatus.

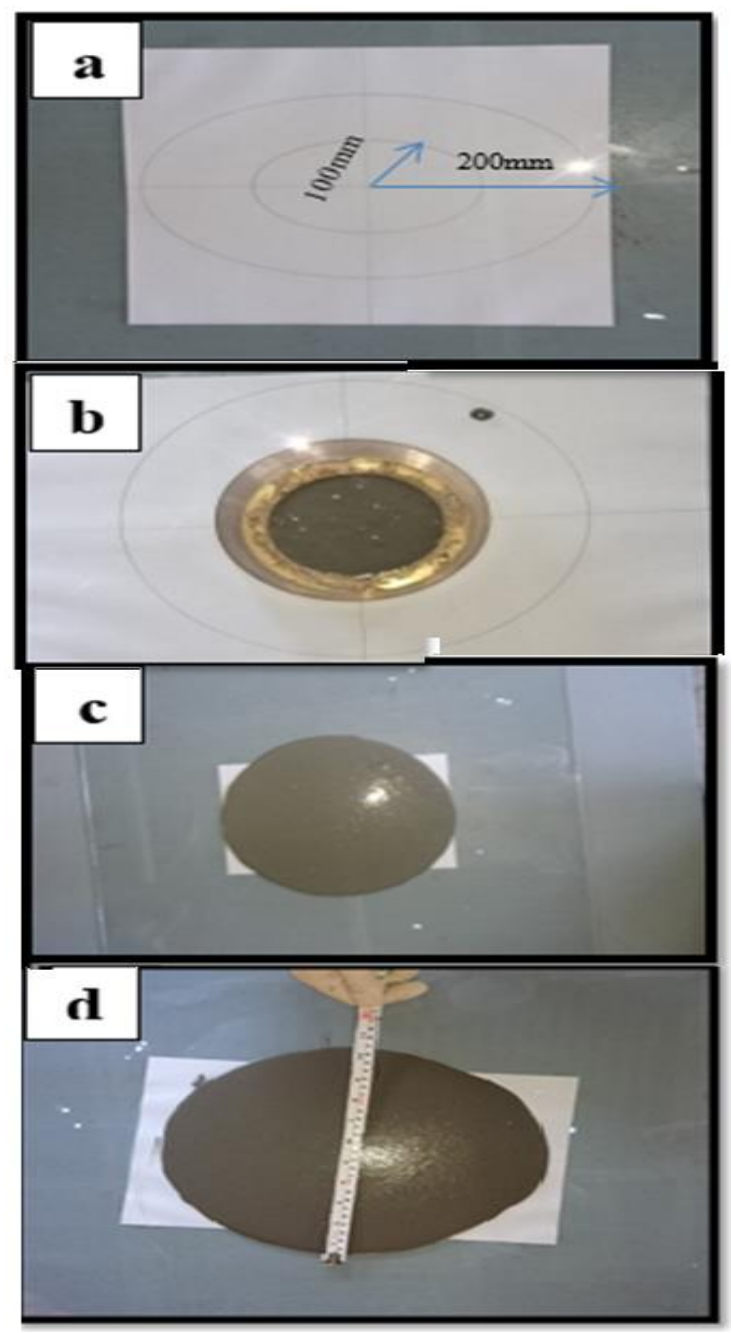

Plate 3. Flow test steps : a) Draw two circle (10\&20) $\mathrm{cm}$. b) Slump cone filled with mortar. c) Flow of mortar. d) Measured appendicular diameter. 


\subsection{Tensile strength of mortar}

Tensile Strength of mortar test was tested according to B.S 6319-7:1985[21]. Briquette mold was used for this test, Plate (5) shows mortar tensile test. The average of three samples was used.

\subsection{Tensile strength for plate specimens}

The specimens are designed with a dimension $(450 \times 100$ $\times 40 \mathrm{~mm}$ ), hydraulic machine of $1000 \mathrm{kN}$ capacity used for this test. To connect the specimens to the test device a re-usable steel connection was designed. In this connection, the specimen is clamped between two steel plates with a length of $100 \mathrm{~mm}$, leaving a measurement area of $250 \mathrm{~mm}$. The tensile stress in the specimen is uniformly introduced by friction between the clamping plates and the specimen element. The 'friction' load in orthogonal direction is provided by pre-tensioning $4 \mathrm{M}$ 20 bolts between two steel plates that run over the clamping plates. To increase the friction coefficient and to prevent stress concentration on the uneven prism surface of the specimen a rubber layer was placed between the steel plates and the prism specimen, LVDT was clamped at the face of the prism specimen and connected to output screen data. Fig. 2 and Plate (6) shows setup of tensile test that was designed, tensile specimen connects to test device by holes and bolts.

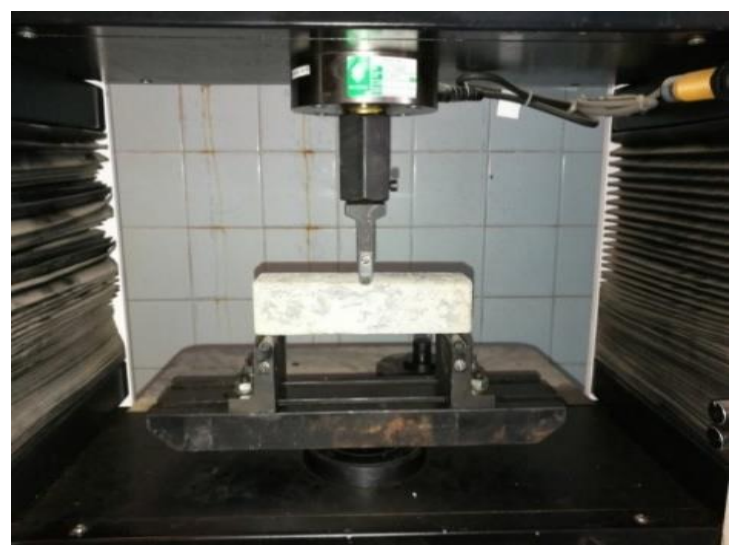

Plate 4. Flexural test for SCM.

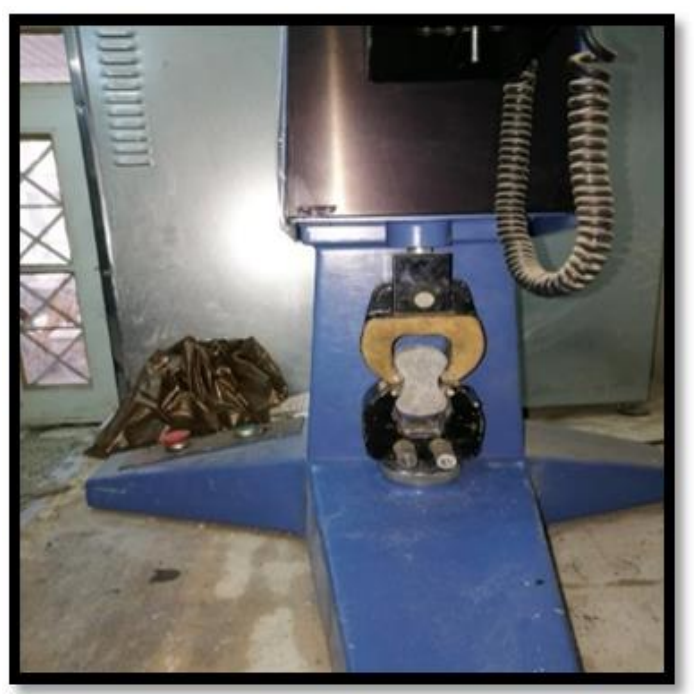

Plate 5. Tensile test for SCM

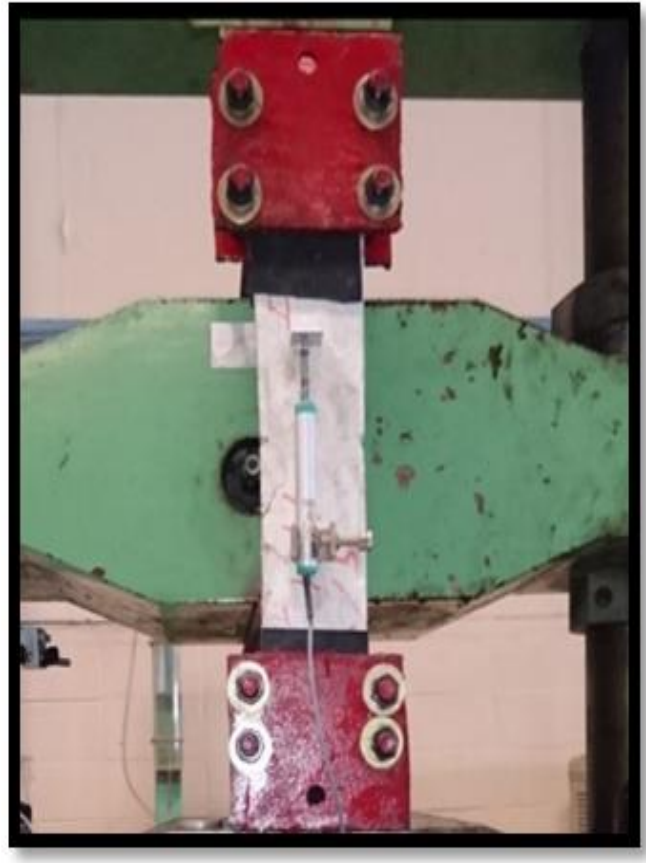

Plate 6. Tensile plate specimen test.

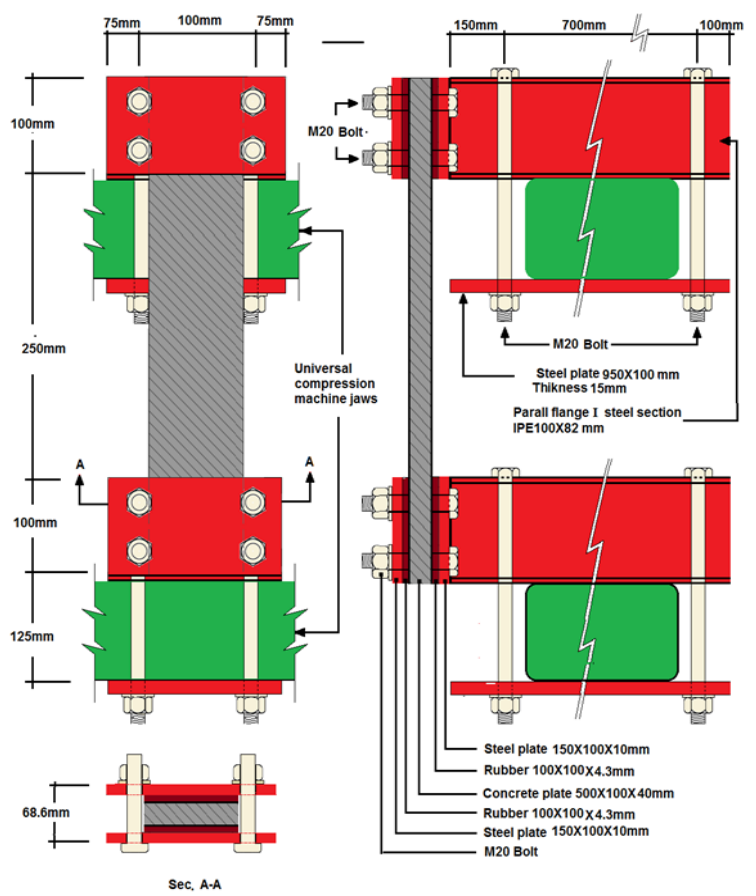

Fig. 2. Tensile test setup.

\section{Results and discussion}

\subsection{Properties of fresh mortar}

The test results relevant to the slump flow diameter, Vfunnel flow time are presented in Table 10. The result shows the mixture had slump flow diameter, V-funnel flow time conforming to [19].

Where Dm is the mean value of the two perpendicular diameters, measured in $(\mathrm{mm})$; Do is the initial diameter of the base of the cone, measured in ( $\mathrm{mm}$ ), and finally, 
the $(\mathrm{t})$ represents the time of flow in the v-funnel, which is measured in seconds.

\subsection{Properties of hardened SCMs}

The hardened properties of the mortars were summarized in Table 11. From results shown in Table 11, the strength increased with ages. This development in compressive strength, tensile strength and flexural strength can be attributed to the continuous hydration process (C-S-H), also presence of silica fume tends basically to consume the calcium hydroxide crystals released from the hydration process leading to the formation of further calcium-silicate-hydrate (secondary C-S-H).

\subsection{Direct tensile strength of plate specimens}

The tensile test was conducted at 28 and 90 days after casting of specimens. During the execution of the tensile tests changes were made to the connection device based on the observations during the experiment, the specimen started to slip out of the connection device at a load of $11 \mathrm{kN}$. This indicates that frictional coefficient between these layers was not sufficient. It was decided to glue the rubber layer on the steel clamping plate, making the connection suitable for testing, and by increasing the pretension in the bolts increased the frictional force between the steel, rubber and concrete. After this measurement, the specimens failed before slipping occurred. Table 12 and Figs (3 - 5) show an overview of the results of the tensile tests.

Table 10. Fresh properties of SCMs

\begin{tabular}{|c|c|c|c|c|}
\hline SCMs & $\begin{array}{c}\text { Slump } \\
\text { Flow } \\
\text { Diameter } \\
\text { (cm) }\end{array}$ & $\begin{array}{c}\mathbf{V}- \\
\text { funnel } \\
\text { time } \\
\text { (s) }\end{array}$ & $G_{m}=\left(\frac{D_{m}}{D_{0}}\right)^{2}-\mathbf{1}$ & $\boldsymbol{R}_{\mathbf{m}}=\frac{\mathbf{1 0}}{\boldsymbol{t}}$ \\
\cline { 2 - 5 } & 25.4 & 9.5 & 5.45 & 1.05 \\
\hline $\begin{array}{c}\text { Acceptance } \\
\text { criteria of } \\
\text { SCMs } \\
\text { suggested } \\
\text { by }[19]\end{array}$ & $24-26$ & $7-11$ & - & - \\
\hline
\end{tabular}

Table 11. Results of hardened properties of SCMs

\begin{tabular}{|l|c|c|c|c|c|c|c|}
\hline $\begin{array}{l}\text { Type of } \\
\text { Test }\end{array}$ & \multicolumn{3}{|c|}{$\begin{array}{c}\text { Compressive Strength } \\
\text { (MPa) }\end{array}$} & \multicolumn{2}{c|}{$\begin{array}{c}\text { Tensile } \\
\text { Strength } \\
\text { (MPa) }\end{array}$} & \multicolumn{2}{|c|}{$\begin{array}{c}\text { Flexural } \\
\text { Strength } \\
\text { (MPa) }\end{array}$} \\
\hline Test & 7 & 28 & 90 & 28 & 90 & 28 & 90 \\
\cline { 2 - 8 } $\begin{array}{l}\text { Age } \\
\text { (days) }\end{array}$ & 45.7 & 61.22 & 77.9 & 3.3 & 5.1 & 5.3 & 9.12 \\
\hline
\end{tabular}

Table 12. Direct tensile strength of plate specimens

\begin{tabular}{|c|c|c|}
\hline Specimen & $\mathrm{F}_{\mathrm{t}}(\mathrm{MPa}) 28$ days & $\mathrm{F}_{\mathrm{t}}(\mathrm{MPa}) 90$ days \\
\hline $\mathrm{R}$ & 3.9 & 4.1 \\
\hline $\mathrm{F} 6-1$ & 4.1 & 4.63 \\
\hline $\mathrm{F} 6-2$ & 4.31 & 5.2 \\
\hline $\mathrm{F} 10-1$ & 4.43 & 4.88 \\
\hline $\mathrm{F} 10-2$ & 4.45 & 5.28 \\
\hline F15 & 4.3 & 4.85 \\
\hline S-1 & 4.2 & 4.4 \\
\hline S-2 & 4.3 & 4.6 \\
\hline MSF & 5.21 & 6.7 \\
\hline
\end{tabular}

The direct tensile strength increases with age for all mixes as shown in Fig. 3, this development in strength can be attributed to the continuous hydration process (C$\mathrm{S}-\mathrm{H}$ ), also presence of silica fume tends basically to consume the calcium hydroxide crystals released from the hydration process leading to the formation of further calcium -silicate- hydrate (secondary C-S-H) and contributing to interfacial bond strength between diverse types of fiber used in present work and the matrix. All fibrous mixes demonstrated higher tensile strength relative to reference $(\mathrm{R}) \mathrm{mix}$ at all ages. Direct tensile strength indicated significant increase in strength due to the inclusion of fibers. From the results shown in Table 12, Figs ( $4 \& 5$ ) the percent of increase in tensile strength was found to be increase with the increase in thickness and number of layers of 3D textile, about (5.13 to $13.6 \%)$, (12.9 to $19 \%$ ) for ages $(28,90$ days) respectively. Also, the increase in tensile strength when reinforced with two layers, about (10.51 to $14.1 \%),(26.8$ to $28.8 \%$ ), for mesh chicken wire increased tensile strength $(7.7,7.3 \%)$ and for two layers about (10.2, $12.2 \%$ ), finally in case of micro steel fiber the increment $(33.6,63 \%)$ at ages $(28,90$ days), this result agree with [12]. This increase in strength is likely due to the bond between the matrix and fibers which increase the possibility of counteracting crack growth and preventing micro-cracks coalescing to form large cracks. The strength increase due to inclusion of steel fibers is attributed to the mechanism of steel fibers in arresting crack progression. Where, the presence of fibers in concrete restrains the development of internal microcracks and thus contributes to an increased tensile strength. Thus, the increase in fiber thickness or fiber layers, i.e. increase in fiber content, leads to an increase in the tensile strength of SCMs as shown in Figs (3- 5). On the other hand, with an increase in fiber content, the fibers become more densely spaced, and they may hinder growth of micro-cracks within the brittle matrix and increase the direct tensile strength of the plates.

All the specimen's testes showed the same failure mode; the failure cracks on each specimen were located near the support and clearly progressed from one to the other side of the specimen. This indicated the specimens were not loaded on pure centric tensile, but on a small bending moment as well, when the failure point of the fiber in the crack stabilizing stage was reached it was observed that the width of the cracks would increase rapidly.

The following reasons are identified that could introduce a bending load on the specimens:

1. The specimens were cast in an open mold, this leads to one smooth surface and one rough surface on the specimen. The friction coefficient of concrete and rubber is likely to be dependent on roughness of the surface. Different friction coefficients on each side of the specimen could lead to an uneven introduction of the tensile stress.

2. Using 4 bolts to apply the load on the clamping plates to introduce the tensile stress by friction, causes 
unequal pre-tension in these bolts, this could lead to uneven introduction of the friction load in the specimen.

After failing of the reinforcement and with decreasing tensile load, the specimens showed a long strain softening trajectory due to the pull-out (friction) of the inner fibers of the yarn, as indicated in Fig. 3, this behavior conformed to [8].

\section{Conclusions}

Based on the results from experimental tests the following conclusions can be drawn for the self-compact mortars reinforced with diverse types of fibers:

1. The direct tensile strength increases with age for all mixes. All fibrous mixes present higher tensile strength relative to reference mix at all ages.

2. The increase in fiber thickness or fiber layers, (i.e. increase in fiber content) leads to an increase in the tensile strength of SCMs.

3. Increase in strength is likely due to the good bond between the matrix and fibers which increase the possibility of counteracting crack growth and prevent micro-cracks coalescing to form large crack.

4. The tested for reference (R) (unreinforced), also $\mathrm{SCM}$ reinforced with mesh chicken wire and micro steel fiber, show the same behavior (failed suddenly and split into two separate parts).

5. 3D textile fibers plates are cracked at failure without separation.

6. The tested specimens showed the same failure mode; the failure cracks on each specimen were located near the support and clearly progressed from one to the other side of the specimen.

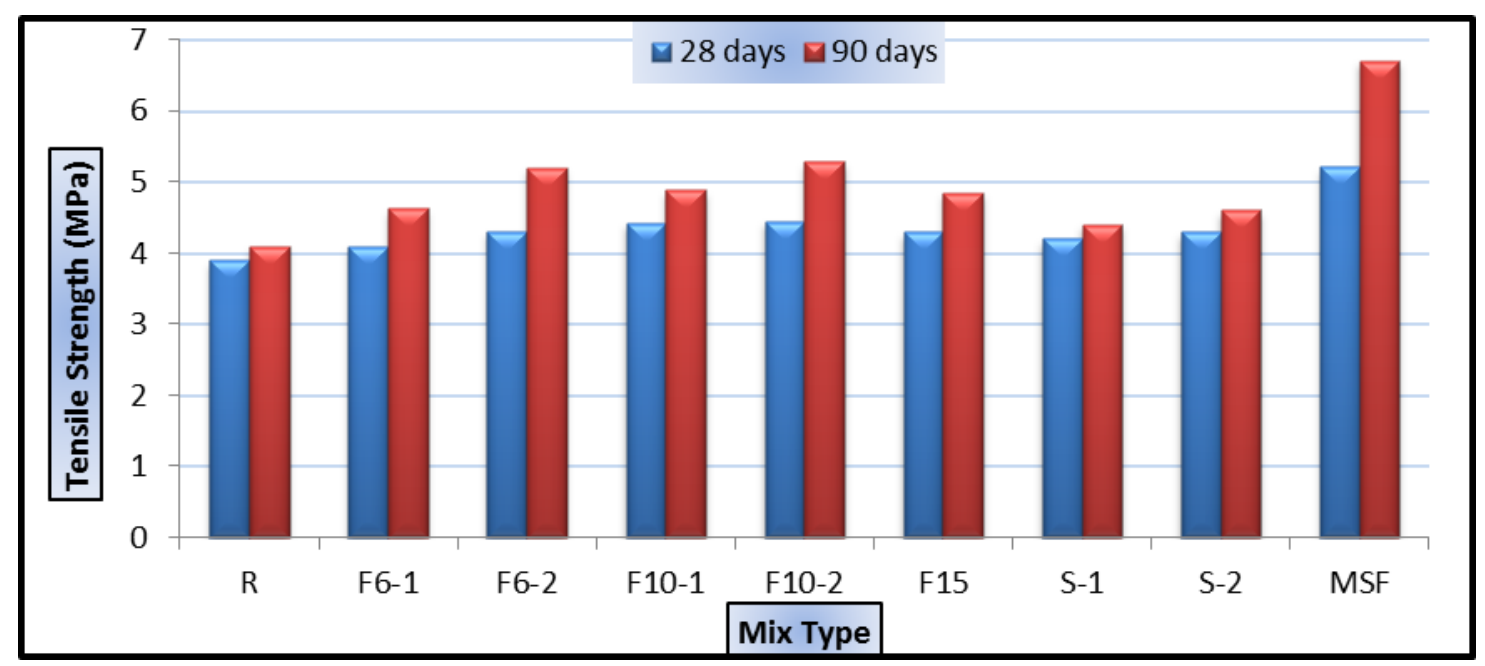

Fig. 3. Direct tensile strength results of plate specimens 


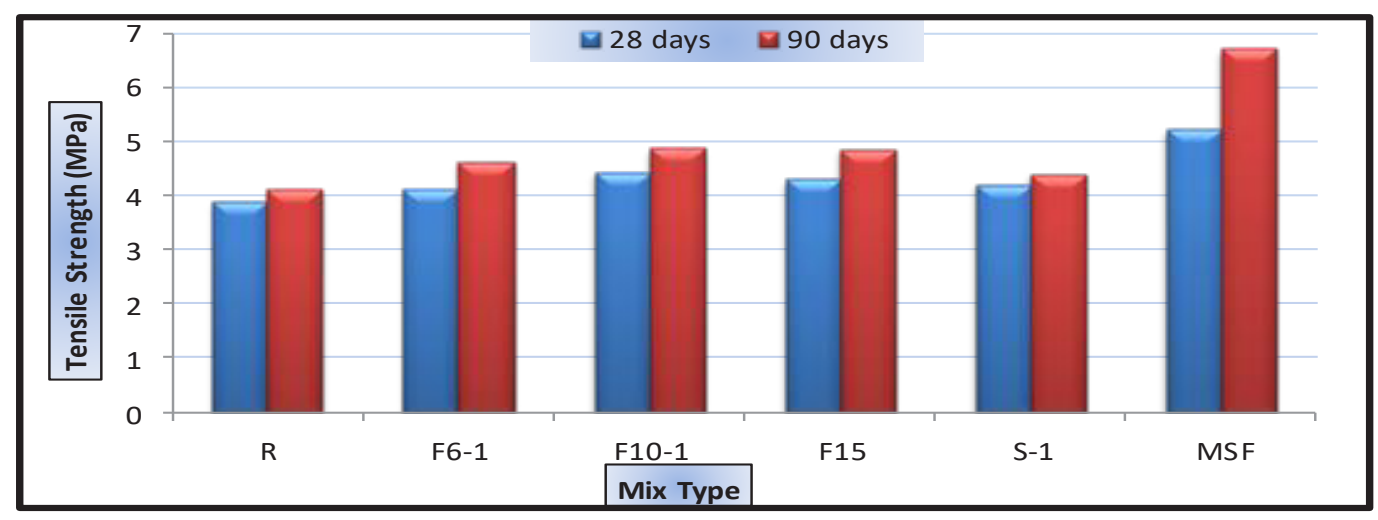

Fig. 4. Direct tensile strength results for one layer reinforcement.

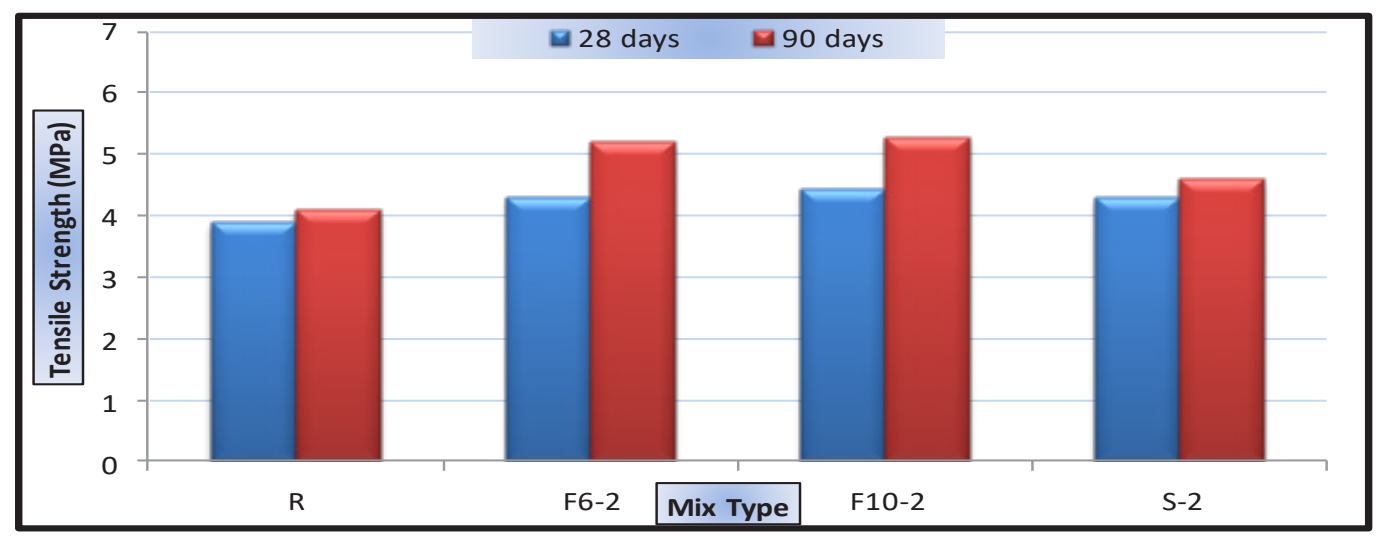

Fig. 5. Direct tensile strength results for two-layer reinforcement.

\section{References}

1. T. C. Triantafillou, C. Papanicolau, Mater. \& Struct. J. E 39, 85 (2007)

2. D. Bournas, P. Lontou, C. G. Papanicolau, T. C. Triantafillou, ACI Struct J 104, 740 (2007)

3. A. L. Dossland, "Fiber Reinforcement in Load Carrying Concrete Structures". Ph.D. Thesis, Norwegian University of Science and Technology, Trondheim, Norway, pp. 254, (March 2008)

4. J. R. Davis, Tensile testing, $2^{\text {nd }}$ edition, ASM international (2004)

5. W. Brameshuber, Textile Reinforced Concrete State-of-the-Art, TC 201-TRC. Bagneux, France. RILEM Publications S.A.R.L. (2006)

6. J. Hegger, J. \& S. Voss, Eng. Struct. E 30, 2050 (2008)

7. H. Fangyu, C. Huisu, J. Kefeng, Z. Wulong, L. Tao, Y. Yujie, Const. \& Build. Mat. J., E 65, 620 (2014)

8. W. T. Lin, R. Huang, C. Lee, \& H. M. Hsu, Journal of Marine Science and Technology, E 16,214, (2008)

9. B. M. Gangadharappa, K. E. Prakash, G. S. Suresh, M. N. Shesha, (IJETCAS), E 5, 239, (2013)

10. S. Eldin, M. Mourad, R. R. No. 47/426 King Saud University, college of engineering research center, (2014)

11. P. S. Parande, D. G. Gaidhankar, (IJRAT), E 2, 2321 (2014)
12. ISQ. No. 5/1984, "Portland cement", COSQC, Iraq

13. ISQ No. 45/1984, "Ruins the natural resources used in concrete construction", COSQC, Iraq

14. ASTM C-494/C 494M-05, "Standard Specification for Chemical Admixtures for Concrete"

15. ASTM C-618-03, "Standard specification for coal fly ash and raw or calcined natural pozzolan for use in concrete"

16. ASTM C-1240-07, "Standard Specification for the Use of Silica Fume as a Mineral Admixture in Hydraulic Cement Concrete, Mortar, and Grout".

17. ASTM C-311-05. "Standard Test Methods for Sampling and Testing Fly Ash or Natural Pozzolans for Use in Portland-Cement Concrete"

18. ASTM C305-04, "Standard Practice for Mechanical Mixing of Hydraulic Cement Pastes and Mortars of Plastic consistency".

19. EFNARC, "Specification and Guidelines for SelfCompacting Concrete". London", UK: Association House, February (2002)

20. ASTM C348-14, "Standard Test Method for Flexural Strength of Hydraulic-Cement Mortars"

21. B.S 6319-7 Part 116,"Method for Determination of Tensile Strength of Mortar", British Standard Institution (1985) 